\title{
DNA variation and polymorphism in Tunisian plum species (Prunus spp): contribution of flow cytometry and molecular markers
}

H. Ben Tamarzizt' ${ }^{1}$, D. Walker ${ }^{2}$, S. Ben Mustapha ${ }^{1}$, D. Abdallah'1 , G. Baraket ${ }^{1}$, A. Salhi Hannachi ${ }^{1}$ and S. Zehdi Azzouzi ${ }^{1}$

${ }^{1}$ Laboratory of Molecular Genetics, Immunology \& Biotechnology,

Faculty of Sciences of Tunis, University of Tunis El Manar, Campus University,

El Manar, Tunis, Tunisia

${ }^{2}$ Departamento de Recursos Naturales,

Instituto Murciano de Investigación y Desarrrollo Agrario y Alimentario (IMIDA),

Estación Sericícola, Calle Mayor s/n, La Alberca, Murcia, Spain

Corresponding author: A. Salhi Hannachi

E-mail: Amel.SalhiHannachi@fsb.rnu.tn

Genet. Mol. Res. 14 (4): 18034-18046 (2015)

Received August 18, 2015

Accepted October 25, 2015

Published December 22, 2015

DOI http://dx.doi.org/10.4238/2015.December.22.30

ABSTRACT. Plums (Prunus spp) are among the most important stone fruit crops in the world. European (Prunus domestica) and Japanese (Prunus salicina) plums are characterized by different levels of ploidy. Because genetic variability is the prerequisite for any plant-breeding program, we aimed to establish the taxonomic status of Tunisian plums and study their genetic variability. The nuclear DNA content of 45 wild and cultivated Tunisian plums was determined by flow cytometry. Two arbitrary primers (AD10, AD17) were used to elaborate SCAR markers useful to identify plum species. Three wild trees, Zenou 1 , Zenou 6 , and Zenou 3 , which had $2 \mathrm{C}$ nuclear DNA contents of $1.99,2.05$, and $2.13 \mathrm{pg}$, were shown to be hexaploid $(2 n=6 x=48)$, whereas the others were diploid $(2 n=2 x=16)$. These results suggest that the three hexaploid wild plums 
belong to Prunus insititia, and the others belong to Prunus salicina. No SCAR markers were revealed using the AD10 and AD17 RAPD primers in relation to the ploidy of plums. We note also that AD17 primer appears to be the most informative concerning the genetic diversity. Morphological and pomological traits revealed similarity between introduced and Tunisian plum cultivars. Despite the significant morphological differences found, all the cultivars studied belong to $P$. salicina. The information obtained in this analysis provided on local plum genetic resources will be helpful to establish a core collection, to evaluate genetic diversity, and to initiate an improvement and selection program.

Key words: Flow cytometry; Plum; Prunus insititia; Prunus salicina; Molecular markers; RAPD

\section{INTRODUCTION}

Prunus is a large and diverse genus of plants that belongs to the subfamily Prunoideae of the family Rosaceae (Rehder, 1940). The genus Prunus comprises about 400 species of trees and shrubs that produce drupes as fruits, commonly called "stone fruits" It is mainly found in temperate regions in both the northern and southern hemispheres, and it constitutes the third most economically important group of plants in the temperate regions of the world. The large number of Prunus species and the frequent interspecific hybridization make the systematic classification in Prunus controversial (Dosba et al., 1994). Plum species occur at three levels of ploidy: diploid, tetraploid, and hexaploid. Prunus domestica L. (6x), which is one of the European plums, is thought to be derived from a natural cross between Prunus spinosa L. (4x) and Prunus cerasifera Ehrh (2x). The term 'Japanese plum' was originally appliedto Prunus salicina Lindl. (2x). The wild species in the Prunus genus constitute an important genetic resource and include species that are used medicinally, as rootstocks, as ornamentals, or for food (Pandey et al., 2008). The introduction of promising cultivars of different species of Prunus and their subsequent selection to fit agro-climatic regions have allowed considerable diversity to develop in major cultivated species, but this also leads to the evolution of new species and varieties and the extinction of local ones. In addition, the introduction of genes from related species through inter-specific hybridization has been used in several breeding programs throughout the world in order to develop better-adapted cultivars and rootstocks. Rootstock breeding programs that use inter-specific hybridization have introduced useful traits, including size control, adaptation to new environments, and pest resistance, thus producing numerous new varieties (Martinez-Gomez et al., 2003). Nevertheless, breeding barriers exist among taxa that possess different ploidy levels, even within the same section like the section Prunophora of the Prunus genus, but hybrids are generally successful when both parents have the same ploidy level (Okie and Weinberger, 1996). In fact, many cultivated genotypes result from cross-pollination making the systematic classification of numerous cultivars extremely difficult. Hence, knowledge of the taxonomic level is important to identify and recognize the gene pool of plum species. Hybridization can induce rapid genomic changes and subsequent changes in the DNA content (Baack et al., 2005). Hence, in recent years, many molecular studies have been established with the aim of identifying and characterizing plum species. Moreover, since tree fruit cultivars are maintained by vegetative propagation, accurate identification of vegetative material is 
crucial for nurserymen and growers, and is needed for plant breeder's rights (Goulao et al., 2001). Therefore, molecular markers, such as restriction fragment length polymorphism (RFLP) (Quarta et al., 1996), random amplified polymorphic DNA (RAPD) (Gregor et al., 1994; Warburton and Bliss, 1996; Ortiz et al., 1997; Bellini et al., 1998; Shimada et al., 1998; Casas et al., 1999; Lisek et al., 2007; Li et al., 2007; Ben Tamarzizt et al., 2009), inter simple sequence repeat (ISSR) (Yilmaz et al., 2009), simple sequence reapet SSR (Mnejja et al., 2004; Baraének et al.,2006; Bouhadida et al., 2009), and amplified fragment length polymorphism (AFLP) (Ilgin et al., 2009), and sequences of non-coding region of chloroplast DNA (Ben Mustapha et al., 2013) have been tested. Knowledge of chromosome number and ploidy level is important, especially in plant families and genera where hybridization between species with different chromosome number or ploidy level occurs frequently.

To clarify the taxonomic status of plums in Tunisia, we investigated the Tunisian germplasm by means of DNA quantification using flow cytometry, RAPD markers generated by AD10 and AD17 primers as suggested by Ortiz et al. (1997) to advance their collection, management, and rational utilization. Flow cytometry constitutes a convenient technique that can be used to study ploidy levels, by estimating the nuclear DNA content (Dolezel et al., 2007), and RAPD markers have proven to be a reliable and useful molecular marker for genetic fingerprinting. The specific aims of this study were to 1) identify the taxonomical status of Tunisian plums, 2) to detect duplicated or mislabeled accessions, 3) to evaluate diversity in order to facilitate its use in breeding and in developing a collection strategy, and 4) to analyze the genetic relationship of plum species, focusing on the origin of local resources.

\section{MATERIAL AND METHODS}

\section{Plant materials}

Forty-five accessions were considered, which represented plum species and their wild relatives. All samples were collected from several localities in northern Tunisia (Ras Jebel, Rafraf, El Alia, Sounine, Ghar El Melh, Douar Hamouda, Bejou, Cap bon, Thibar, Djebba, and Kairouan) (Table1).

\section{Genomic DNA extraction}

Total cellular DNA was purified from young frozen leaves according to two procedures: Bernatzky and Tanksley (1986) and a modified procedure as described by Ahrens and Seemüller (1992). The DNA quality was examined by electrophoresis on $0.8 \%$ agarose gels, as described by Sambrook et al.(1989), and the DNA concentration was quantified spectrophtometrically.

\section{Flow cytometry procedure}

Estimation of nuclear DNA content was performed with a Partec PA II flow cytometer (Partec GMBH, Münster, Germany). The method was based on the protocol described by Bukhari (1997). Samples of growing leaf tissue of Prunus and soya were prepared together. Soya has a $2 \mathrm{C}$ nuclear DNA content of $2.50 \mathrm{pg}$. Leaf material was chopped with a razor blade for 30-60 s, in a 60$\mathrm{mm}$ plastic Petri dish containing $0.4 \mathrm{~mL}$ extraction buffer (Cystain PI absolute P, Partec GMBH), to which polyvinylpyrrolidone-10 $(2.5 \% \mathrm{w} / \mathrm{v})$, ascorbic acid $(12 \mathrm{mM})$, dithiothreitol $(9 \mathrm{mM})$, and Triton $\mathrm{X}-100$ detergent $(0.25 \% \mathrm{v} / \mathrm{v})$ had been added. The resulting extract was passed through a $30-\mathrm{mL}$ 
filter into a 15-mL centrifuge tube. The Petri dish was washed twice with $0.8 \mathrm{~mL}$ extraction buffer and the samples were thenfiltered into the $15-\mathrm{mL}$ tube. After centrifugation at $1.100 \mathrm{~g}$ for $10 \mathrm{~min}$, the supernatant was removed and the pellet was re-suspended in $1.6 \mathrm{~mL}$ Cystain PI absolute P staining buffer (Partec $\mathrm{GMBH}$ ) to which propidium iodide and RNase had been added (final concentrations of 50 and $17.5 \mu \mathrm{g} / \mathrm{mL}$, respectively). All stages of the extraction were performed at $4^{\circ} \mathrm{C}$. The samples were kept in the dark for $15 \mathrm{~min}$ at $37^{\circ} \mathrm{C}$, before being filtered through a $30-\mathrm{mL}$ filter. The linearity of the cytometer fluorescence scale was checked regularly using propidium iodide-stained calibration beads (Partec GMBH). At least 5000 nuclei were analyzed in each sample. The equivalent number of base pairs was calculated assuming that 1 pg DNA = $978 \mathrm{Mbp}$ (Dolezel et al., 2007; Greilhuber et al., 2007). One-way ANOVA was performed using SAS (1990), version 6.12. The mean nuclear DNA content was tested by the Student-Newman-Keler test (5\%), using SPSS v.11.0.

Table 1. Tunisian plums studied and their locality of origin.

\begin{tabular}{|c|c|}
\hline Cultivar & Locality \\
\hline Bedri1 & Ras jebel \\
\hline Japonia safra & Rafraf \\
\hline Janha & Rafraf \\
\hline Ain kounoulia & Rafraf \\
\hline Cidre1 & Rafraf \\
\hline Adham hmém & Rafraf \\
\hline Neb zarouk & Rafraf \\
\hline Hamda & Rafraf \\
\hline Aouina hamra badri & Rafraf \\
\hline Ain thaer noman & Rafraf \\
\hline Golden Japan & El Alia \\
\hline Ain torkia & Rafraf \\
\hline Santa Rosa1 & Rafraf \\
\hline Aouina safra morra & Rafraf \\
\hline Zaghwénia & Rafraf \\
\hline Ain tasstouria & Sounine \\
\hline Ain ben moussa & Rafraf \\
\hline Baydha arbi & Rafraf \\
\hline Meski kahla1 & Rafraf \\
\hline Meski safra1 & Rafraf \\
\hline Meski kahla2 & Rafraf \\
\hline Bedri2 & Ras jebel \\
\hline Bedri hamra1 & Capbon \\
\hline Black Gold & Kairouan \\
\hline Bedri hamra2 & Kairouan \\
\hline Bedri hamra3 & Kairouan \\
\hline Bedri hamra4 & Kairouan \\
\hline Stanley & Capbon \\
\hline Golden Japan2 & Capbon \\
\hline Sauvage1 & Thibar \\
\hline Chaaraouiya & Ghar el melh \\
\hline Zenou5 & Douar Hamouda \\
\hline Zenou1 & Douar Hamouda \\
\hline Cidre 2 & Ghar el melh \\
\hline Jelya1 & Bejou \\
\hline Golden Japan3 & Ghar el meleh \\
\hline Zenou6 & Douar hamouda \\
\hline Zenou3 & Douar Hamouda \\
\hline Jelya2 & Bejou \\
\hline Zenou7 & Douar Hamouda \\
\hline Sauvage3 & Djebba \\
\hline Black diamond & Capbon \\
\hline Sandid & Rafraf \\
\hline Safra jridi & Rafraf \\
\hline Santa Rosa2 & Capbon \\
\hline
\end{tabular}




\section{RAPD analysis}

Two RAPD primers were tested: AD10 (AAGAGGCCAG) and AD17 (GGCAAACCCT) according to Ortiz et al. (1997), these primers produce specific patterns for diploid and hexaploid species. The reactions were carried out in a $25 \mu \mathrm{L}$ volume reaction mixture containing $20 \mathrm{ng}$ total cellular DNA, 50 pM primer, $2.5 \mu \mathrm{LTaq}$ DNA polymerase buffer, $1.5 \cup$ Taq DNA polymerase (QBIOgéne, France), and $200 \mathrm{mM}$ dNTP (DNA polymerization mix, Pharmacia). The PCRs were then performed in a DNA thermocycler (TC 512, TECHNE) programmed to execute the following cycles: reaction mixtures were heated at $94^{\circ} \mathrm{C}$ for $5 \mathrm{~min}$ as an initial denaturation step before entering 35 cycles, each composed of $30 \mathrm{~s}$ at $94^{\circ} \mathrm{C}, 1 \mathrm{~min}$ at $35^{\circ} \mathrm{C}, 1 \mathrm{~min}$ at $72^{\circ} \mathrm{C}$, and a final step of $5 \mathrm{~min}$ at $72^{\circ} \mathrm{C}$. To reduce the possibility of cross contamination in the amplifications, reaction mixtures without DNA were used as negative controls. Only reproducible products were taken into account for further data analysis. The products of amplification were separated on $1.5 \%$ agarose gel at 100 $\mathrm{mV}$ for $2 \mathrm{~h}$ in $0.5 \mathrm{X}$ TBE buffer and detected after ethidium bromide staining according to the method described by Sambrook et al. (1989). To confirm the results, acrylamide gels (10\%) were also used.

\section{Data analysis}

Polymorphic RAPD bands were scored as present (1) or absent (0) across the 45 genotypes for two RAPDs primers as a binary data matrix. The percentage of polymorphic bands (PPB) was estimated and the ability of RAPD tested primers to differentiate between plums was appreciated by the estimation of their resolving power (Rp) (Prevost and Wilkinson, 1999) The Rp has been described by Gilbert et al. (1999) such that: $R p=\sum \mid b$ where: $\mid b=1-(2 x|0.5-p|)$ where $p$ is the accessions proportion containing the I band. The generated binary matrix was computed with the Gendist program (version 3.572c), using the computer program PHYLIP (phylogeny inference package, version 3.5c) (Felsenstein 1995), producing a genetic distance matrix according to the formula described by Nei and Li (1979). The neighbor program produces a tree-file using the unweighted pair group method with the arithmetic averaging (UPGMA) algorithm.

\section{RESULTS}

\section{DNA quantification}

Quantification of DNA by flow cytometry (Table 2, Figure 1) suggests that genome size of the Tunisian plum cultivars studies varies significantly. Of the 45 accessions studied, three wild trees 'Zenou 1', 'Zenou 6', and 'Zenou 3', which had 2C nuclear DNA contents of 1.99, 2.05, and $2.13 \mathrm{pg}$, respectively, were shown to be hexaploid $(2 n=6 x=48)$, whilst the others $(0.44-0.97 \mathrm{pg}$ DNA) were diploid $(2 n=2 x=16)$. The wild tree 'Zenou1' contained the highest number of bases (2083.1 Mbp) and cultivar 'Hamda' contained the lowest, $432 \mathrm{Mbp}$ (Table 3). The results also show that the ploidy of the introduced cultivars: 'Black gold'; 'Black diamond'; 'Golden Japan', and 'Santa Rosa' were diploid and included in $P$. salicina.

\section{Molecular markers}

Here we used two RAPD primers that were suggested by Ortiz et al. (1997) to be able 
to differentiate between diploid and hexaploid plum and generate specific SCAR markers that are useful to define the taxonomy statute of Tunisian plum species. The results of the RAPD analysis of 54 plum genotypes are given in Table 3 and Figure 2. Molecular polymorphism was revealed, as demonstrated by RAPD patterns and no specific markers were detected in relation to the ploidy level of plums. Nine and 10 RAPD markers were generated by the AD10 and AD17 primers. Percent polymorphic bands were 90 and 100 for AD10 and AD17, respectively. The AD17 primer appears to be the most informative with a resolving power of $6.4(\operatorname{Rp}$ of AD10 $=5.5)$.

Table 2. $2 \mathrm{C}$ nuclear DNA contents, the equivalent number of base pairs, and the corresponding ploidy for the Prunus cultivars studied.

\begin{tabular}{|c|c|c|c|}
\hline Cultivar & DNA (pg) & DNA (Mbp) & Ploidy \\
\hline Ain kounoulia & 0.626 & 612 & Diploid \\
\hline Ain torkia & 0.672 & 656 & Diploid \\
\hline Ain thaer noman & 0.520 & 508 & Diploid \\
\hline Ain ben moussa & 0.681 & 666 & Diploid \\
\hline Ain tasstouria & 0.459 & 449 & Diploid \\
\hline Aouina hamra badri & 0.457 & 447 & Diploid \\
\hline Aouina safra morra & 0.567 & 554 & Diploid \\
\hline Adham hmém & 0.635 & 620 & Diploid \\
\hline Baydha arbi & 0.683 & 667 & Diploid \\
\hline Bedri1 & 0.598 & 584 & Diploid \\
\hline Bedri2 & 0.559 & 547 & Diploid \\
\hline Bedri hamra1 & 0.483 & 471 & Diploid \\
\hline Bedri hamra2 & 0.642 & 628 & Diploid \\
\hline Bedri hamra3 & 0.634 & 619 & Diploid \\
\hline Bedri hamra4 & 0.730 & 713 & Diploid \\
\hline Janha & 0.691 & 676 & Diploid \\
\hline Hamda & 0.443 & 432 & Diploid \\
\hline Japonia safra & 0.799 & 781 & Diploid \\
\hline Safra jridi & 0.668 & 653 & Diploid \\
\hline Neb zarouk & 0.634 & 619 & Diploid \\
\hline Sandid & 0.614 & 600 & Diploid \\
\hline Zaghwénia & 0.650 & 636 & Diploid \\
\hline Cidre1 & 0.578 & 564 & Diploid \\
\hline Cidre2 & 0.544 & 532 & Diploid \\
\hline Meski kahla1 & 0.616 & 602 & Diploid \\
\hline Meski kahla2 & 0.637 & 623 & Diploid \\
\hline Meski safra1 & 0.892 & 872 & Diploid \\
\hline Chaaraouiya & 0.555 & 542 & Diploid \\
\hline Jelya1 & 0.971 & 949 & Diploid \\
\hline Jelya2 & 0.956 & 934 & Diploid \\
\hline Sauvage1 & 0.689 & 674 & Diploid \\
\hline Sauvage3 & 0.636 & 622 & Diploid \\
\hline Zenou1 & 2.130 & 2083 & Hexaploid \\
\hline Zenou3 & 1.995 & 1951 & Hexaploid \\
\hline Zenou5 & 0.539 & 527 & Diploid \\
\hline Zenou6 & 2.050 & 2005 & Hexaploid \\
\hline Zenou7 & 0.699 & 684 & Diploid \\
\hline Black Gold & 0.517 & 505 & Diploid \\
\hline Black diamond & 0.624 & 609 & Diploid \\
\hline Stanley & 0.615 & 601 & Diploid \\
\hline Golden Japan1 & 0.587 & 574 & Diploid \\
\hline Golden Japan2 & 0.765 & 747 & Diploid \\
\hline Golden Japan3 & 0.715 & 699 & Diploid \\
\hline Santa Rosa1 & 0.551 & 538 & Diploid \\
\hline Santa Rosa2 & 0.699 & 683 & Diploid \\
\hline
\end{tabular}

Following ANOVA $(P<0.001$ for the effect of "cultivar"), the LSD values obtained $(P<0.05)$ were $0.184 \mathrm{pg}$ for the nuclear DNA content and $180 \mathrm{Mbp}$ for the equivalent number of base pairs. 

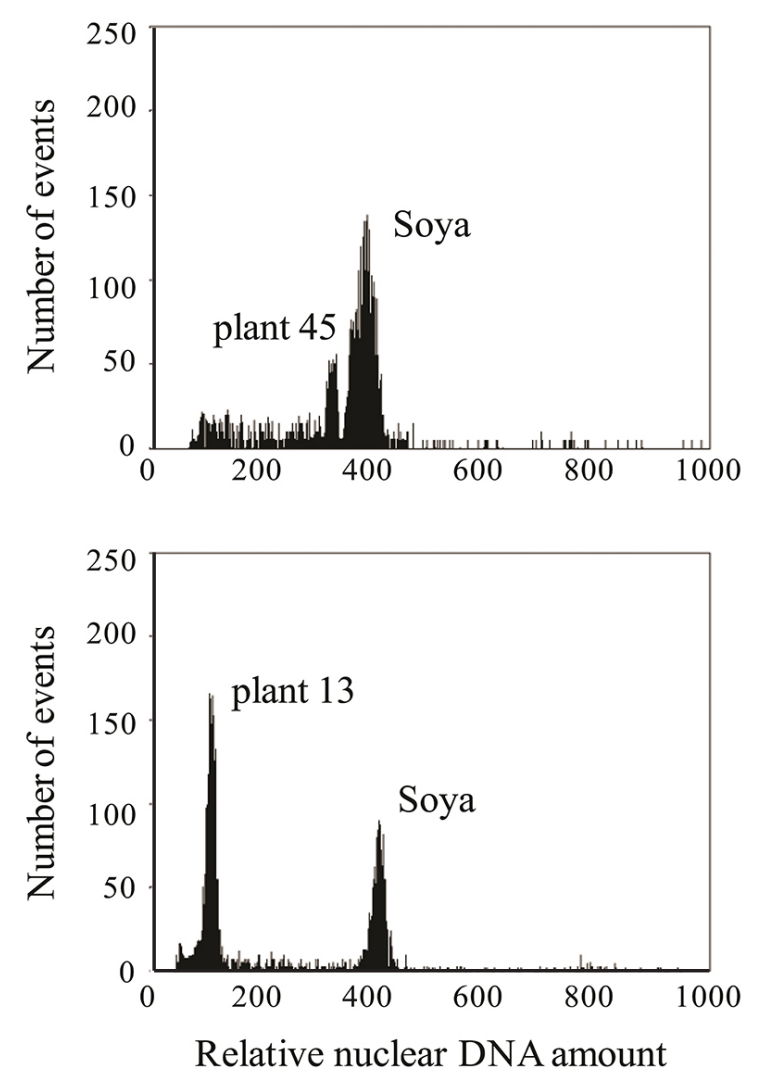

Figure 1. Histogram of the relative nuclear DNA content of Prunus plants 13 (Prunus salicina; cultivar Ain torkia) and 45 (Prunus insititia; cultivar Zenou6), determined by flow cytometry analysis of propidium iodide-stained nuclei with soya (Glycine max; 2C nuclear DNA content $2.50 \mathrm{pg}$ ) as an internal standard. Nuclei of Prunus and soya leaves were isolated, stained, and analyzed simultaneously.

The genetic distances (Nei and $\mathrm{Li}, 1979$ ) ranged from 0.00 to 1.33 with a mean of 0.53 , which suggest a high level of polymorphism at the genomic DNA level of the studied accessions. The lowest distance value (0.00) was observed between ['Ain kounouliya' and 'Adham hmem']; ['Ain kounouliya' and 'Golden Japan1']; ['Cidre1' and 'Golden Japan1']; ['Meski kahla1' and 'Bedri hamra3']; ['Meski safra1' and 'Bedri hamra2'] cultivars, which seem to be closely related. While the highest distance of 1.33 was calculated between ['Neb zarrouk' and 'Meski safra1']; ['Meski kahla1' and 'Sauvage1']; ['Bedri1' and 'Sauvage1']; ['Ain torkia' and 'Safra jridi']; ['Golden Japan2' and 'Safra jridi'] accessions, suggesting their divergence. Topology of the UPGMA dendrogram (Figure 3) shows that varieties can be classified into two main clusters, the first one labeled $(\mathrm{I})$ is subdivided into two subgroups (la and Ib), which contain wild and introduced cultivars, respectively. The second group is divided into two major subgroups (Ila and IIb), which contain the remaining accessions analyzed. Some cultivars presented an important similarity ['Meski safra1' and 'Meski kahla2']; ['Meki kahla1' and 'Bedri2]; ['Ain taher noman' and 'Ain kounouliya' 'Cidre1']; ['Sandid' and 'Safra jridi'] despite their appellation; these may be explained by misidentification or homonymy problems. 
Table 3. Random amplified polymorphic DNA (RAPD) markers generated by AD10 and AD17 primers.

\begin{tabular}{|c|c|c|c|}
\hline \multirow[t]{2}{*}{ Cultivar } & \multirow{2}{*}{$\frac{\text { AD10 }}{1140 \mathrm{bp}}$} & \multicolumn{2}{|c|}{ AD17 } \\
\hline & & $890 \mathrm{bp}$ & $520 \mathrm{bp}$ \\
\hline Ain kounoulia & - & - & - \\
\hline Ain torkia & - & + & + \\
\hline Ain thaer noman & - & - & - \\
\hline Ain ben moussa & + & + & - \\
\hline Ain tasstouria & + & + & + \\
\hline Aouina hamra badri & + & + & - \\
\hline Aouina safra morra & + & - & - \\
\hline Adham hmém & + & + & - \\
\hline Baydha arbi & + & - & - \\
\hline Bedri1 & + & - & - \\
\hline Bedri2 & + & - & - \\
\hline Bedri hamra1 & - & + & - \\
\hline Bedri hamra2 & - & + & - \\
\hline Bedri hamra3 & + & + & - \\
\hline Bedri hamra4 & + & + & - \\
\hline Janha & - & + & - \\
\hline Hamda & + & + & - \\
\hline Japonia safra & - & + & + \\
\hline Safra jridi & + & + & - \\
\hline Neb zarouk & - & + & - \\
\hline Sandid & - & - & - \\
\hline Zaghwénia & + & - & + \\
\hline Cidre1 & - & + & - \\
\hline Cidre2 & - & - & - \\
\hline Meski kahla1 & + & + & - \\
\hline Meski kahla2 & + & + & - \\
\hline Meski safra1 & + & + & - \\
\hline Chaaraouiya & + & + & - \\
\hline Jelya1 1 & + & + & + \\
\hline Jelya2 & + & - & - \\
\hline Sauvage1 & + & + & - \\
\hline Sauvage3 & + & + & - \\
\hline Zenou1 & + & + & - \\
\hline Zenou3 & + & + & - \\
\hline Zenou5 & + & - & - \\
\hline Zenou6 & + & + & - \\
\hline Zenou7 & + & - & - \\
\hline Black Gold & - & + & - \\
\hline Black diamond & + & + & - \\
\hline Stanley & - & - & - \\
\hline Golden Japan1 & + & - & - \\
\hline Golden Japan2 & + & + & - \\
\hline Golden Japan3 & + & + & - \\
\hline Santa Rosa1 & + & - & - \\
\hline Santa Rosa2 & - & - & - \\
\hline
\end{tabular}

+: presence; -: absence of bands.

\section{DISCUSSION}

Little is known about the taxonomic status of the Tunisian plum germplasm. Results of DNA quantification suggest that the three hexaploid wild plums belong to the species Prunus insititia and all the other cultivars to Prunus salicina, taking into account their diploidy. The wild tree 'Zenou1', which belongs to $P$. insititia, had the highest number of bases (2083.1 Mbp) and cultivar 'Hamda' ( $P$. salicina) had the lowest number of bases (432 Mbp). The results also confirm the ploidy of the introduced cultivars: 'Black gold'; 'Black diamond'; 'Golden Japan', and 'Santa Rosa' were diploid and included in P. salicina, as suggested by Goulao et al. (2001). The cultivar 'Stanley' was thought to belong to the hexaploid species $P$. domestica; however, flow cytometry showed that 
this cultivar is diploid and must be included in $P$. salicina. In this case, flow cytometry permitted the detection and resolution of mislabeling problems. All the remaining cultivars were found to be diploid. In fact, the accessions 'Sauvage1', 'Sauvage3', 'Chaaraouiya', 'Jelya1', and 'Jelya2', which are considered wild cultivars, do not belong to the spontaneous species $P$. insititia or $P$. spinosa. All the other cultivars are diploid and could belong to $P$. salicina. These findings corroborate the work of Mzali et al. (2002) on the basis of morphological characteristics.

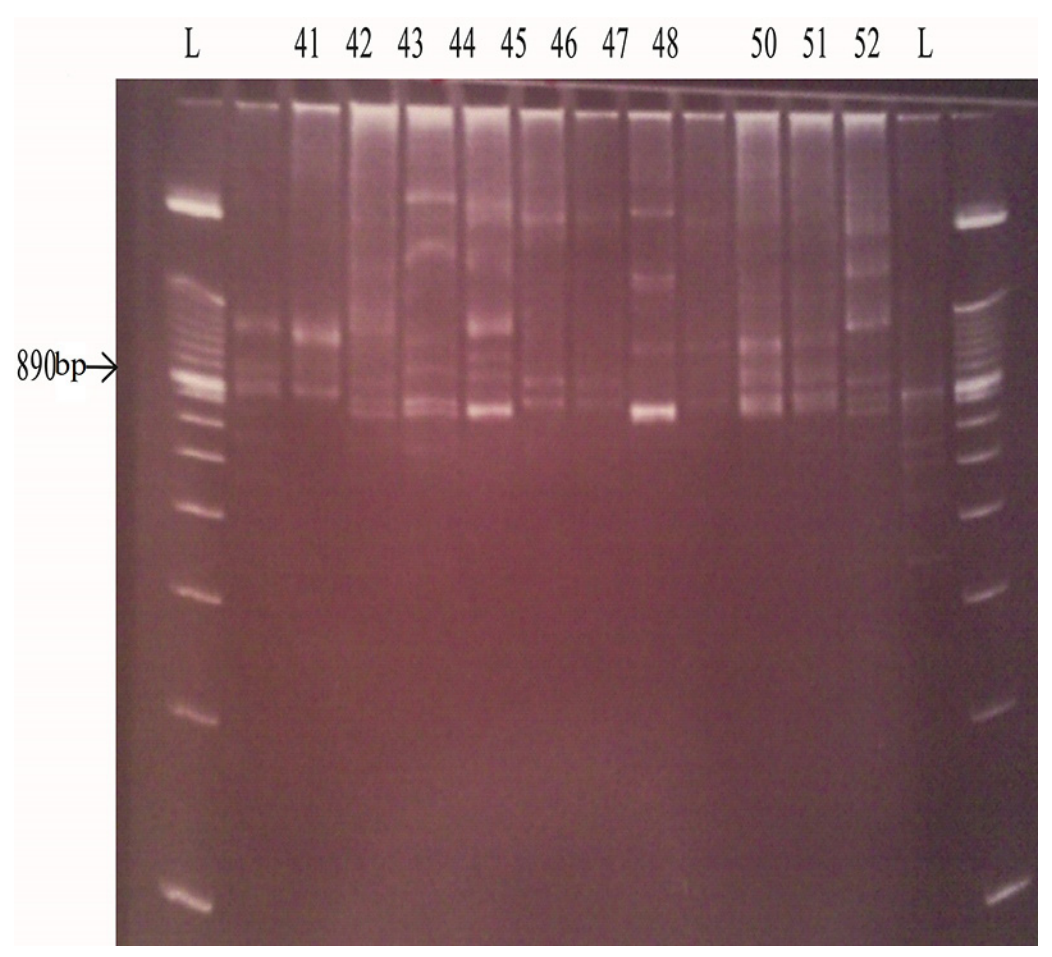

Figure 2. Random amplified polymorphic DNA (RAPD) patterns generated by the AD17 primer. Lanes: L = Ladder (100 bp; Invitrogen); 41 = Zenou1; 42 = Cidre2; 43 = Jelya1; 44 = Golden Japan3; 45 = Zenou6; 46 = Zenou3; 47 = Jelya2; 48 = Zenou $7 ; 50$ = Sauvage $; ; 51=$ Black diamond; 52 = Sandid.

Polymorphisms at the DNA level have been used in several studies to examine genetic diversity in plums. Previous molecular studies on plums using RAPD markers revealed wide genetic polymorphism among accessions (Gregor et al.,1994; Ortiz et al., 1997; Bellini et al., 1998; Shimada et al., 1999; Lisek et al., 2007; Liu et al., 2007; Ben Tamarzizt et al., 2009), which was explained by the floral biology and different ploidy levels. As demonstrated by Ortiz et al. (1997), use of the arbitrary primers, AD10 and AD17, yields polymorphic amplification products that are specific to the diploid or hexaploid species. In fact, primer AD10 produces a fragment of approximately $1140 \mathrm{bp}$, which is present only in the Japanese plum. The primer AD17 produces only two patterns, one specifically for the European and the other for the Japanese plum cultivars. These patterns were distinguished by one fragment of approximately $890 \mathrm{bp}$ that is specific to Japanese cultivars and an other amplification product of approximately $520 \mathrm{bp}$ that is characteristic of the European cultivars (Ortiz et al., 1997). Here, we used the AD10 and AD17 primers to reveal the specific markers. 




Figure 3. UPGMA dendrogram based on RAPD markers showing the relationships among plum cultivars.

The results reported here are not consistent with those of previous studies investigating RAPD markers as descriptors of the diploid and hexaploid plum species, since the amplified fragments (1140 bp produced by AD10 and 890 bp produced by AD17), which should identify diploid trees (Ortiz et al., 1997), are also amplified in the hexaploid 'Zenou1'; 'Zenou3', and 'Zenou6'. Similarly, the 1140-bp band produced by the AD10 primeris absent in some diploid samples: 'Japounia safra'; 'Janha'; 'Ain kounoulia'; 'Cidre1'; 'Neb zarouk'; 'Ain Taher noman'; 'Ain torkia'; 'Bedri hamra1'; 'Bedri hamra2'; 'Black gold'; 'Stanley'; 'Cidre2', and 'Santa Rosa 2'. Additionally, the AD17 primer that is used to amplify a specific band present in diploids (890 bp) was also tested (Figure 2). This 890-bp fragment was obtained in all cultivars except 'Bedri1'; 'Ain kounoulia', 'Ain taher noman', 'Santa Rosa1', 'Aouina safra morra', 'Ain zaghwénia', 'Aouina arbi baydha', 'Bedri2', 'Stanley', 'Zenou5', 'Zenou7', 'Cidre2', 'Jelya2', 'Sandid', and 'Santa Rosa 2'. These 
results contradic those obtained by flow cytometry. Indeed, according to the flow cytometry results, 'Bedri1', 'Ain kounoulia', 'Ain Taher noman', 'Santa Rosa1', 'Aouina safra morra', 'Ain zaghwénia', 'Aouina arbi baydha', 'Bedri2', 'Stanley', 'Zenou5', 'Zenou7', 'Cidre2', 'Jelya2', 'Sandid', and 'Santa Rosa 2' cultivars are diploids. Similarly, the characteristic 520bp fragment, which should be present only in hexaploid plums and is amplified using the AD17 primer (Ortiz et al., 1997), was observed in the diploids 'Japounia safra', 'Ain torkia', 'Ain zaghwénia', 'Ain tasstouria', and 'Jelya1'. These results do not confirm the findings of Ortiz et al. (1997) and the specific RAPD markers do not allow the generation of SCAR markers to recognize plum species. Flow cytometry data reveals that there is intra- and inter-specific DNA variation (Table 3). Trees of the same variety did not present equivalent DNA contents, namely ['Cidre1'; 'Cidre2'], ['Golden Japan1'; 'Golden Japan2'; 'Golden Japan3'], and ['Santa Rosa1'; 'Santa Rosa2']. This variation is also observed among the wild trees ['Zenou1'; 'Zenou3'; 'Zenou5'; 'Zenou6'; 'Zenou7'].

Cluster analysis of plum cultivars revealed a strong distinctness of the genotypes from different geographical regions. As shown by Figure 3, plums are grouped independently of their ploidy level. Cultivar distribution occurs separately from their geographic origins, so typically continuous genetic diversity characterizes local plum germplasm. Additionally, we note that hexaploid cultivars ['Zenou1', 'Zenou3', and 'Zenou6'] do not diverge from diploid cultivars, which confirms the previous results.

\section{Comparison between phenotypic analysis and flow cytometry}

Morphological analysis of 20 accessions was performed and important inter-cultivar phenotypic variability was observed by Ben Tamarzizt et al. (2009). Principal component analysis (PCA ) was performed using 25 morphological and pomological parameters and showed that there was similarity between the introduced variety 'Santa Rosa' and the local variety 'Cidre1 according to their pomological traits related to fruit and seed characteristics: 'Fruit form', 'Skin color', 'Firmness', 'Juiciness', and 'Acidity'. The introduced cultivars do not differ from the Tunisian ones, indicating the good performance of local cultivars (Ben Tamarzizt et al., 2009). It is important to note that flow cytometry clustered these varieties in the same group of diploid trees, belonging to the Japanese species P. salicina. Thus, this cultivar is more important than the introduced one 'Santa Rosa', which have resulted from selection by American breeders such as Luther Burbank since 1883 (Shimada et al., 1999) and Wellington (USA) (Anonymus, 2002; Ben Tamarzizt et al., 2009). Furthermore, significant divergence between local cultivars was observed, especially between "Ain Tasstouria" and "Meski safra 1". In fact, these two Tunisian plums are morphologically distant according to their leaf, branch, fruit, and seed parameters: 'Leaf length', 'Branch length 2006', 'Branch length 2007', 'Fruit length', 'Fruit width', 'Fruit weight', 'Fruit form', 'Skin color', 'Pulp color', 'Firmness', 'Acidity', 'Aroma', 'Sweetness', and 'Seed form. Furthermore, similar varieties, with similar morphological traits, were observed, especially for trees of the same varieties ['Meski kahla 1'; 'Meski kahla 2'] according to their branch, leaf, fruit, and seed parameters. Additionally, the clusters were independent to the geographic origin of the plum cultivars. In this analysis, dispersion of cultivars in the PCA plot appears without any clear aggregation correlated to geographical origin. Despite major differences in morphological appearance, all tested trees have the same ploidy level and belong to the Japanese species $P$. salicina. In fact, many pomological traits were discriminating and characterized each variety. This result can be explained by the environmental adaptation of different varieties. 
Morphological study has revealed wide genetic polymorphism among plum accessions, because plums are a very complex group, which includes diploid, tetraploid, and hexaploid species, and because floral biology differs among plum groups (Erturk et al., 2009). The distribution of cultivars occurs independently from their geographic origin. We also note that introduced and Tunisian plums are clustered together in the PCA plot, confirming the efficiency of the local germplasm. These results underline the importance of preserving the genetic resources of plum species since this may enable breeders to select the most diverse genotypes, with interesting fruit characteristics, for crossing and selection programs.

\section{Conflicts of interest}

The authors declare no conflict of interest.

\section{ACKNOWLEDGMENTS}

Research supported by grants from the Tunisian "Ministère de l'Enseignement Supérieur et de la Recherche Scientifique".

\section{REFERENCES}

Ahrens $U$ and Seemüller E (1992). Detection of DNA of plant pathogenic mycoplasma-like organisms by a polymerase chain reaction that amplifies the sequence of the 16S rRNA gene. Phytopathology 82: 828-832.

Anonymus (2002). Arboricultures fruitières. Variétés fruitières reccomandées en Tunisie. Documents techniques INRAT $n^{\circ} 114$.

Baack EJ, Whitney KD and Rieseberg LH (2005). Hybridization and genome size evolution: timing and magnitude of nuclear DNA content increases in Helianthus homoploid hybrid species. New Phytol. 167: 623-630.

Baraének M, Raddová J and Pidra M (2006). Comparative analysis of genetic diversity in Prunus L. as revealed by RAPD and SSR markers. Sci. Hortic. 108: 253-259.

Bellini E, Giordani E, Nencetti V and Paffetti V (1998). Genetic releationships in Japanese plum cultivars by molecular markers. Acta Hortic. 478: 53-69.

Ben Mustapha S, Ben Tamarzizt H, Baraket G, Abdallah D, et al. (2013). A signature of balancing selection in the plastid trnL UAA intron and investigation of the phylogenetic relationships among Tunisian plum species (Prunusspp).Sci. Hortic. 151:51-56.

Ben Tamarzizt H, Baraket G, Ben Mustapha S, Marrakchi M, et al. (2009). Genetic relatedness among Tunisian plum cultivars by random amplified polymorphic DNA analysis and evaluation of phenotypic characters. Sci Hortic. 121: 440-446.

Bernatzky R and Tanskley SD (1986). Genetics of actin-related saquences in tomato. Theor. Appl. Genet. 72: 314-321.

Bukhari YM (1997). Cytoevolution of taxa in Acacia and Prosopis (Mimosaceae). Australian J. Bot. 45: 879-891.

Casas AM, Igartua E, Balaguar G and Moreno MA (1999). Genetic diversity of Prunus rootstocks analyzed by RAPD markers. Euphytica 110: 139-149.

Dolezel J, Greilhuber J and Suda J (2007). Estimation of nuclear DNA content in plant using flow cytometry. Nat. Protoc. 2: 2233-2244.

Dosba F, Bernhard R, Zanetto A (1994). Importance des ressources génétiques des Prunus. Comptes Rendus de l'Académie d'Agriculture de France. 80: 45-57.

Erturk Y, Ercisli S, Maghradze D, Orhan E, et al. (2009). An assessment of genetic variability and relationships among wildgrown (Prunus spinosa L.) plants based on RAPD markers. Genet. Mol. Res. 8: 1238-1244.

Gilbert JE, Lewis RV and Wilkinson MJ (1999). Developing an appropriate strategy to assess genetic variability in plant germplasm collections. Theor. Appl. Genet. 98: 1125-1131.

Goulao L, Monte-Corvo L and Oliveira CM (2001). Phenetic characterization of plum cultivars by high multiplex ratio markers: Amplified Fragment Length Polymorphisms and Inter-simple Sequence Repeats. J. Am. Soc. Hort. Sci. 126: 72-77.

Gregor D, Hartmann W and Stösser R (1994). Cultivar identification in Prunus domestica using random amplified polymorphic DNA markers. Acta Hortic. 359: 33-40.

Greilhuber J, Temsch EM and Loureiro JCM (2007). Nuclear DNA measurement flow cytometry. In: Plant Cells (Dolezel J, 
Greilhuber J, Suda J, eds.). Wiley VCH, New York, 67-101.

Ilgin M, Kafkas S and Ercisli S (2009). Molecular characterization of plum cultivars by AFLP markers. Biotechnol. Biotech. Eq. 1189-1193.

Lisek A, Korbin M, Rozpara E and Zurawicz E (2007). Plum cultivar DNA polymorphism generated with RAPD and ISSR markers. Acta Hortic. 734: 281-285.

Liu W, Li S, Zhang A and Liu D (2007). Genetic diversity revealed by RAPD markers in plum collection of China. Acta Hortic. 734: 287-294.

Martinez-Gomez P, Sozzi OG, Sanchez-Perez R, Rubio M, et al. (2003). New approaches to Prunus tree crop breeding. Food Agric. Environ. 1: 52-63.

Mnejja M, Garcia-Mas J, Howad W, and Arùs P (2004). Development and transportability across Prunus species of 42 polymorphic almond microsatellites. Mol. Ecol. Notes 5: 531-535.

Mzali MT, Lasram M, Rhouma A (2002). L'arboriculture fruitière en Tunisie. In: Les arbres à noyaux et le palmier dattier (INRAT, ed.). 2: $171-200$.

Nei M and Li WH (1979).Mathematical model for studying genetic variation in terms of restriction endonuclease.Proc. Natl. Acad. Sci. U.S.A.76: 5269-5273.

Okie WR and Weinberger JH (1996). Plums. In: Fruit Breeding, vol 1. Tree and Tropical Fruits (Janick J and Moore JN, eds.). Wiley, New York.

Ortiz A, Renaud R and Calzada land Ritter E (1997). Analysis of plum cultivars with RAPD markers. J. Hortic. Sci. 72: 1-9.

Pandey A, Nayar ER, VenkateswaranK and Bhandan DC (2008). Genetic resources of Prunus (Rosaceae) in India. Genet. Res. Crop Evol. 55: 91-104.

Quarta R, Dettori MT, Verde I, Laino P, et al. (1996). Characterization and evaluation of genetic diversity in peach germplasm using RAPD and RFLP markers. Acta Hortic. 546: 489-496.

Rehder A (1940). A Manual of Cultivated Trees and Shrubs Hardy in North America Exclusive of the Subtropical and Warmer Temperate Regions, 2nd edn. New York: Macmillan, 162.

Sambrook J, Fritsch E and Fand Maniatis T (1989). Molecular cloning: a laboratory manual (Cold spring Harbor Laboratory, ed.). Cold Spring Harbor, New York.

Shimada T, Hayama H, Haji T, Yamagguchi M, et al. (1999). Genetic diversity of plums characterized by random amplified polymorphic DNA (RAPD) analysis. Euphytica 109: 143-147.

Warburton ML and Bliss FA (1996). Genetic diversity in peach (Prunus persica L. Batch) revealed by randomly amplified polymorphic DNA (RAPD) markers and compared to inbreeding coefficients. J. Am. Soc. Hort. Sci. 121: 1012-1019.

Yilmaz UK, Ercisli S, Asma BM, Dogan Y, et al. (2009). Genetic Relatedness in Prunus Genus Revealed by Inter-simple Sequence Repeat Markers. Hort. Sci. 44: 293-297. 